\title{
The Effect of Regional Original Income, Balanced Funds and Capital Expenditures on Financial Performance of Regency/City Governments in The Special Region of Yogyakarta in 2010-2019
}

\author{
Asih Sriwinarti' ${ }^{1}$ Wahyu Dwi Artaningtyas ${ }^{2}$ \\ ${ }^{1}$ Faculty of Economics and Business, Universitas Pembangunan Nasional "Veteran" Yogyakarta
}

\begin{abstract}
The financial enforcement of local governments is one dimension that can guarantee regions' ability to explore and manage local financial sources to support the government system and regional development without moving utterly reliant on the central government. One of the regional financial performance measurement tools is the regional independence ratio. Regencies/Cities in DIY are regions whose financial performance is still relatively different. Therefore, it needs to investigate the factors that are the matter. The purpose of this study was to analyze the effect of Regional Original Income, Balanced funds, and Capital Expenditures on the financial performance of Regency/City Governments in the Special Region of Yogyakarta. The data adopted in this research is panel data, a combination of data for time-series 20102019, and a cross-section of five regencies/cities in DIY. The result of panel data regression analysis shows that the Regional Original Income and Capital Expenditure have a positive and significant effect. In contrast, the Balanced fund has a negative and significant effect on the financial performance of the regency government in DIY.
\end{abstract}

Keywords: Regional Financial Performance, Balanced funds, Capital Expenditures

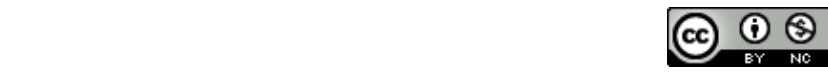

This is an open access article under the CC-BY-NC license

\section{INTRODUCTION}

Regional autonomy depends on Law no. 32 of 2004, which aims to increase independence and reduce the financial dependence of local governments on the central government. In this case, it means that local governments are required to have a better regional financial performance where regions will none longer depend on the assistance of the central government or in other words, regions are required to be independent of the financial side of the region. The higher the level of financial independence, the regions can provide higher quality public services. Therefore, performance measurement is very important, especially in managing regional finances to assess government accountability and managing regional original financial resources in matching their requirements to maintain the running of the government system, government service to the community, and regional development by having flexibility in using funds for the benefit of the local community within limits determined by laws and regulations. Performance measurement is a way to determine the realization of good local government performance (Noviyanti and Kiswanti, 2016).

One of the analytical techniques used to examine financial performance records is Financial Ratio Analysis. Financial Ratio Analysis is a proposition to recognize financial components based on possible financial reports, which is done by calculating the regional independence ratio. Halim (2007) states that 
the size of local revenue indicates regional financial independence compared to regional income from different roots, such as principal government assistance or loans. The level of regional financial independence can be used as an indicator to assess the performance of the regional government, whether it has been running optimally or not.

Data so far shows that the percentage of Regional Original Income (PAD) in almost all regions is relatively smaller than the total regional revenue. In general, the APBD (Regional Revenue and Expenditure Budget) of a region is dominated by contributions from the central government and other contributions, which are regulated by laws and regulations. This caused the regions to depend on the central state emerging in the experience of the regions to develop their potential become very limited, or in other words, the level of independence is still low. The low PAD of a region is not because structurally the region is poor or does not have potential financial sources, but is mainly caused by central government policies. So far, the potential sources of finance are controlled by the prime authority. Like other regions, the regime/city administration in the Special Region of Yogyakarta (DIY) also experienced the same thing where the level of independence was still low.

Table 1. The ratio of Regency/City Financial Independence in the Special Region of Yogyakarta in 20102019 (Percent)

\begin{tabular}{|c|c|c|c|c|c|}
\hline \multirow{2}{*}{ Year } & \multicolumn{5}{|c|}{ Level of Financial Independence in Regency/City in DIY } \\
\cline { 2 - 6 } & Yogyakarta & Sleman & Bantul & Kulon Progo & Gunungkidul \\
\hline 2010 & 37,02 & 22,03 & 11,85 & 9,95 & 6,71 \\
\hline 2011 & 45,72 & 30,07 & 17,97 & 10,29 & 8,17 \\
\hline 2012 & 56,16 & 31,80 & 18,82 & 12,09 & 8,38 \\
\hline 2013 & 58,15 & 45,25 & 23,89 & 14,09 & 7,59 \\
\hline 2014 & 70,91 & 55,43 & 34,48 & 22,40 & 17,24 \\
\hline 2015 & 78,22 & 61,13 & 37,49 & 23,40 & 20,04 \\
\hline 2016 & 61,74 & 54,26 & 30,38 & 18,83 & 16,64 \\
\hline 2017 & 75,41 & 61,82 & 38,39 & 26,50 & 21,70 \\
\hline 2018 & 76,93 & 65,34 & 34,13 & 21,68 & 17,95 \\
\hline 2019 & 78,72 & 70,88 & 37,56 & 22,87 & 19,26 \\
\hline Average score & 63,90 & 49,80 & 28,50 & 18,21 & 14,37 \\
\hline
\end{tabular}

Source: DJPK Ministry of Finance 2021 (data processed)

During the last ten years, the level of financial independence of the authorities/cities in DIY has different independence ratios where the city of Yogyakarta is one of the regions with the highest independence ratio while the level of independence in Gunungkidul Regency is very low. The city of Yogyakarta has a moderate financial capacity, or its financial performance has a participatory pattern in which government intervention is getting less and less because the regional independence is getting higher and higher. Sleman Regency and Bantul Regency have low financial performance, or their financial performance has a consultative pattern where government intervention has begun to decrease slightly because the capacity of local governments has begun to increase. Kulonprogo and Gunungkidul have very low financial performance, or their financial performance has an instructive pattern. There is still much central government intervention. 
The financial independence of a region is certainly influenced by many factors, such as human resource factors, the potential of regional natural resources, and the quality of local government. This research analyzes the effect of Original Regional Income, Balanced funds, and Capital Expenditures on Financial Performance as measured by the Financial Independence Ratio of Regency/City Governments in DIY. Many studies that examine the success of local government financial performance have been carried out using various factors. These factors include PAD, DAU, DAK (Abdullah, Asmawanti and Febriansyah 2015), PAD and Balanced fund (Andriani and Wahid, 2018). Tjahjono and Oktavianti (2016), using the Effectiveness Ratio of PAD, General Allocation Fund (DAU), and Special Allocation Fund (DAK) variables. Malau and Parapat (2020), using the PAD and Capital Expenditure variables. Machfud et al. (2020) and Tahir et al. (2019), using the PAD variables, balanced funds, and Special Autonomy Funds. The factors used in this study also refer to research conducted by Noholo and Yusuf (2016) by taking the variables of PAD, balanced funds, and capital expenditures related to financial performance. Then the research of Indriyani and Sastradipraja (2014) uses PAD variables, balanced funds, other legitimate regional income.

The increasing PAD is expected to fulfill the local government's public services obligations to the community. Higher the PAD, the financial performance of the local government will increase so that it can finance development activities for the welfare of the people in the area. The Balanced fund affects the Financial Performance of the Regional Government, where the greater the balanced fund received from the central government, the lower the regional independence. Then the third factor, namely capital expenditure, is a budget used to add fixed assets and other assets that produce gains for more than one accounting term and pass the tiniest limit toward capitalization of fixed assets set by the government. Capital expenditure shows an increase in investment made so that the higher the regional financial performance (Christy and Ady, 2008).

\section{LITERATURE REVIEW}

\section{Internal Regional Autonomy}

Internal regional autonomy (Law Number 22 of 1999) is broad autonomy, namely the existence of regional authority to manage the government, which includes all areas of government excluding the authority in the areas of international policy, decision, monetary and fiscal, defense and security, religious, and other fields of authority stipulated by a Government Regulation. In addition, the freedom of autonomy and authority is complete and unanimous in its implementation, starting from planning, implementation, supervision, control, and evaluation. The purpose of regional autonomy is a form of democracy that the central government supplies to regional governments to take responsibility for their household while still adhering to the applicable laws and regulations. Autonomy is used as a major limiter and extent of autonomous regions and the relationship of power between the central and regional governments to avoid autonomous regions becoming a State within a State. Autonomous regions are certain territorial boundaries that have the right, authority, and obligation to regulate and manage their household (Halim, 2007).

\section{Regional Finance}

Regional Finance is all local priorities and commitments in the circumstances of managing the territorial state, which can occur appreciated in currency, include specific forms of wealth associated with the advantages and commitments of the district, inside the structure of the Regional Revenue and Expenditure Budget (Law No. 58 of 2005). Regional finance is also defined as all rights and commitments 
that can be valued in currency, as well as all units, both in the application of money and goods, which can be applied as local assets since they are not controlled by region or more powerful regions and other parties below the requirements of relevant rules and regulations (Mamesa, 1995).

\section{Regional Financial Performance}

Regional financial achievement is that sense from a province to examine and maintain local independent economic sources in meeting its requirements to assist the court system, service to the society, and local growth without being wholly helpless on the primary authority and having the versatility in using funds for the advantage of the regional population within boundaries restricted by laws and regulations. According to Mardiasmo (2002), the public division production capacity policy means a system to support public administrators in evaluating a strategy's performance within financial and nonfinancial measure tools. The performance computation system can be applied as an essential regulatory tool because it is strengthened by establishing a reward and punishment system.

\section{RESEARCH METHOD}

\section{Types and sources of data}

This study used descriptive quantitative research. The quantitative descriptive analysis approach consists of formulating the problem, compiling a model to present the data, finding solutions, analyzing the results, and implementing the results (Kuncoro, 2004). The data needed in this study is the Regency/City APBD data in DIY 2010-2019, which is sourced from the Directorate General of Fiscal Balance, Ministry of Finance.

\section{Operational DefinitionVariables}

a. Regional Financial Performance is measured using the regional independence ratio, which shows how much a region's ability to finance government activities, regional development, and public services. The formula for the Area Financial Independence (Ratio in percent) is:

$$
\text { Regional Independence Ratio }=\frac{\text { Regional Original Income }}{\text { Central/Provincial Government Assistance }} \times 100 \%
$$

b. Regional Original Revenue is a beginning of original regional revenue dug up in the district to be used as the essential capital of the local government in funding development and regional forces to reduce dependence on stores from the central state. PAD consists of local taxes, local levies, distributed regional wealth management results, and other authorized regional revenues.

c. A balanced fund is sourced from APBN revenues designated to districts to finance local requirements consisting of Revenue Sharing Funds, Special Allocation Funds, and General Allocation Funds.

d. Capital Expenditure is an allocation of regional expenditure to obtain capital goods in the form of goods that have benefits for more than 12 months or one accounting period. The capital expenditure in the form of land, buildings, infrastructure, and others. Capital expenditure is used for the operational interests of an area in which to improve the quality of public services.

\section{Analysis Tool}

In analyzing the performance of the Yogyakarta Special Region Government, the analytical tool that will be used is panel data for the regression analysis. The model in this comparison where the independent variable was changed in the form of logarithm Natural (LN): 


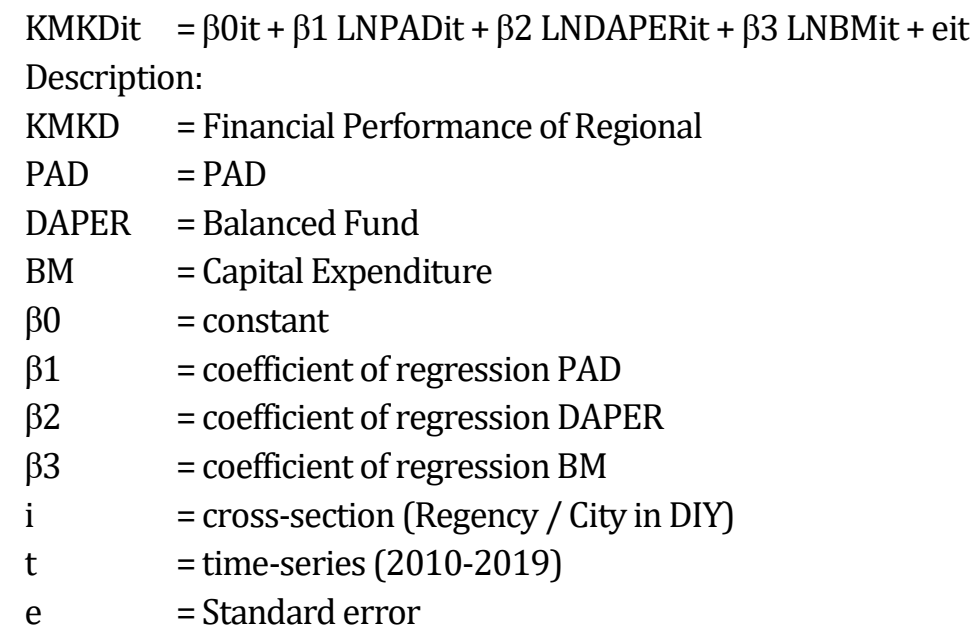

Several model approaches can be applied to estimate model parameters with panel data. The Common Effect Model (CEM) or Pooled Least Square (PLS) is the most uncomplicated panel data design because this consolidates time series data with data cross-section. This design ignores the dimensions of time or individuals, so it can be assumed that the behavior of the data is the same in the various periods used. This approach uses the Ordinary Least Square technique to estimate the model. Fixed Effect Model (FEM) is a model that assumes that differences between individuals can be accommodated from differences in intercepts. The Fixed Effects Model uses a dummy variable technique to capture differences in intercepts between companies to estimate panel data. Diversity in intercepts can happen due to variations in work habits, also managerial, and then incentives.

Nevertheless, the slop is the same among groups. This estimate treatment is usually named the technique Least Squares Dummy Variable (LSDV). The random effect model estimates panel data where the disturbance variables may occur interrelated over time and among selves. In the Random Effect Model, the differences in intercepts are provided by the error terms of each group. The benefit of using the Random Effect Model can reduce heteroscedasticity. This design is named the Error Component Model (ECM) or the Generalized Least Square (GLS) technique.

\section{Model Specification}

The Chow Test (likelihood) is a tool to test between the fixed effect model or the common effect model chosen. If the model test results show the probability of Chi-Square $>$ being used (0.05), then the model chosen is Common Effect models. However, if the probability of Chi-Square < is used (0.05), then Ha is accepted, and Ho is rejected, so the model chosen is Fixed Effect models. The Hausman test is a model test that is used to choose between Fixed Effect Model or Random Effect Model, which should be chosen. If the results of the model test show the probability of Chi-Square $>(0.05)$, the model chosen is the Random Effect Model. However, if the probability of Chi-Square < $(0.05)$, then Ha is accepted and Ho is rejected so that the model chosen is Fixed Effect Model. The Lagrange Multiplier Test, the LM test, should be performed when the results of the Chow test and the Hausman test show that both accept Ho and reject Ha. The Lagrange Multiplier test is a model test used to choose between the Common Effect Model or Random Effect Model selected. If the model test results show the probability value of Chi-Square $>(0.05)$, then the model chosen is the Common Effect Model. However, if the probability of Chi-Square $<(0.05)$, 
then Ha is accepted and Ho is rejected so that the chosen model is the Random Effect Model (Widarjono, 2013).

\section{Statistical Test}

The coefficient of determination test (R2) is a coefficient value that shows the significance of the change in the dependent variable, which is influenced by the variation of the independent variable. The Partial Test to decide whether a particular variable has a significant effect upon the dependent variable. F test (simultaneous test) determines that all independent variables simultaneously or jointly affect the dependent variable significantly. The basis of decision-making for partial and simultaneous tests will be carried out using a significant level of $5 \%(0.05)$.

\section{FINDINGS AND DISCUSSION Model Selection/Specification}

Chow Test (likelihood)

The Chow test in this research is used to choose the fixed effect model that can be used, or another common effect model will choose.

Table 2. The Chow Test Data Result

Redundant Fixed Effects Tests

\begin{tabular}{|l|c|c|c|}
\hline $\begin{array}{c}\text { Cross-section } \\
\text { Effects }\end{array}$ & Statistic & df & Prob. \\
\hline (F) & 5.895620 & $(4.42)$ & 0.0007 \\
\hline Chi-square & 22.281950 & 4 & 0.0002 \\
\hline
\end{tabular}

Source: Processed Data

The results show that the value probability Chi-Square is 0.0002 smaller than 0.05 , so the model that should be applied in the design is a fixed effect. While the chosen model is a fixed effect, it is necessary to do another test called the Hausman test to determine is better to use a fixed-effect model or a random effect model.

\section{Hausman test}

The Hausman is used to conclude whether we should use a fixed-effect model or a random effect model.

Table 3. The Hausman Test Result

\begin{tabular}{|l|c|c|c|}
\hline $\begin{array}{l}\text { Cross-section } \\
\text { Test }\end{array}$ & $\begin{array}{c}\text { Chi-square } \\
\text { statistics }\end{array}$ & Chi-square. df & Prob. \\
\hline random-section & 6.335645 & 3 & 0.0964 \\
\hline
\end{tabular}

Source: Processed Data

Based on the results above, shows the probability of random cross is 0.0964 higher than 0.05 ; the model that should use in this research is the random effect model. Because Hausman test results indicate choosing Random Effect Model, a Lagrange Multiplier to test is needed. It aims to define the common effect model or the random effect that should be selected. 
RSF Conference Series: Business, Management and Social Sciences, Vol. 1 (3), 147-156

The Effect of Regional Original Income, Balanced Funds and Capital Expenditures on Financial Performance of

Regency/City Governments in The Special Region of Yogyakarta in 2010-2019

Asih Sriwinarti, Wahyu Dwi Artaningtyas

\section{Panel Data Regression Results}

Based on the specification test or model selection that has been carried out, the model selected is the Random Effect Model. The estimation results of the panel data regression model are as follows.

Dependent Variable: KMKD?

Table 4. Results of Panel Data Regression

Method: Pooled EGLS

Sample: 110

\begin{tabular}{crrrr}
\hline \hline Variable & Coefficient & Std. Error & t-Statistic & Prob. \\
\hline \hline C & $237.9750^{*}$ & 128.1516 & 1.856981 & 0.0697 \\
LN_PAD? & $25.76886^{*}$ & 2.670747 & 9.648561 & 0.0000 \\
LN_DAPER? & $-37.83572^{*}$ & 7.062624 & -5.357176 & 0.0000 \\
LN_BM? & $6.216681^{*}$ & 2.916317 & 2.131689 & 0.0384 \\
Random Effects & & & & \\
(Cross) & & & & \\
_BANTUL--C & -3.418303 & & & \\
_GUNUNGKIDUL--C & 0.513200 & & & \\
_KULON_PROGO--C & -4.812002 & & & \\
_SLEMAN--C & 2.216971 & & & \\
_YOGYAKARTA--C & 5.500135 & & & \\
\hline \hline R-squared & 0.821979 & & & \\
Adjusted R-squared & 0.810369 & & & \\
SE of regression & 5.698470 & & & \\
F-statistic & 70.79882 & & & \\
Prob(F-statistic) & 0.000000 & & & \\
\hline \hline
\end{tabular}

*Sig on $\alpha=0,05$

Source: Processed Data

The results show probability value of PAD (Regional Original Income) is 0.0000 . The probability of DAPER (Balanced Fund) is 0.0000 , and the probability value of BM (Capital Spending) of 0.0384 . This means that the PAD (Regional Original Income), DAPER (Balanced fund), and Capital Expenditure Result is a significant effect on the alpha level of $5 \%(0.05)$ because the probability is less than 0.05 . Simultaneously the three variables significantly affect regional economic performance with a probability value of 0.0000 less than 0.05 alpha. The coefficient of determination is 0.821979 , which means that 8.1979 percent of the variation in the regional economic performance of the Regency in DIY can be explained by variations in the PAD, Balanced Fund, and Capital Expenditure variables.

The PAD variable has a positive and significant effect where every 1 percent increase in PAD will cause an increase in regional financial performance by 25.76886 percent. This shows that an increase in PAD can improve regional financial performance because, with an increase in PAD, the region will be able to meet its regional financing. The Balanced fund variable has a negative and significant effect where every 1 percent increase in the Balanced fund will decrease the regional financial performance by 37.83572 percent. Seeing the considerable influence of the Balanced fund on the economic performance of local governments, the Local Governments in DIY still need to work even harder in optimizing the potential of 
their regions so that dependence on the center can be minimized and financial performance can be further improved. Capital Expenditures Result in a positive and vital impact on the economic accomplishment of Regency Management in DIY, where every 1 percent rise in Capital Expenditures directions increase Regional economic Performance by 6.216681. More development transferred out will raise the local financial performance, where the more sources that are produced, the more the results will be. The above conditions indicate that the development process carried out has been right on target, or all of them have led to efforts to optimize the region's potential. Capital expenditure in DIY is relatively low, and its effectiveness needs to be further improved to have a tangible impact on development needs in the DIY region.

\section{CONCLUSION AND FURTHER RESEARCH}

This research proposes to analyze the impact of PAD, Balanced Fund, and Capital Expenditure variables on the Financial Administration of Regency Management in DIY in 2015-2019. The results obtained are that PAD has a positive and significant effect, and Balanced fund has a negative and significant effect, while Capital Expenditures can not affect Regional Financial Performance.

Regency Governments in DIY should continue to strive to increase capital expenditures and allocate them to development that can encourage the optimization of PAD so that financial performance will increase and dependence on the center will be lower. Alternatively, in other words, Regency Management in DIY needs to pay attention to the allocation of regional expenditures while still considering the positive impact on PAD and regional income. This study only includes financial variables that transform the financial performance of Regency Governments in DIY. Therefore, future research suggests the need to include non-financial variables in the model, such as economic growth variables.

\section{REFERENCES}

Abdullah, Asmawanti, D \& Febriansyah 2015, 'Pengaruh Pendapatan Asli Daerah, Dana Alokasi Umum, dan Alokasi Khusus Terhadap Kinerja Keuangan Pemerintah Daerah Kabupaten/Kota SeSumatera Bagian Selatan', Jurnal Akuntansi (Universitas Bengkulu), vol. 3, no. 1, hh. 41-67.

Andriani, RNR, \& Wahid, NN 2018, 'Pengaruh Pendapatan Asli Daerah dan Dana Perimbangan terhadap Kemandirian Keungan Daerah (Studi Kasus Pada Pemerintah Kota Tasikmalaya Tahun 20062015)', Jurnal Akuntansi, vol. 13, no. 1, hh. 30-39.

Christy, FA, \& Adi, PH 2008, 'Hubungan Antara Dana Alokasi Umum, Belanja Modal Dan Kualitas Pembangunan Manusia', The 3 Rd National Conference UKWMS Surabaya.

DJPK, 2021, Data APBD Kabupaten/Kota Daerah Istimewa Yogyakarta Tahun 2010-2019, Kementerian Keuangan Direktorat Jenderal Perimbangan Keuangan, TGL AKSES, https://www.djpk.kemenkeu.go.id.

Halim, A \& Damayanti 2007, Pengelolaan Keuangan Daerah, Seri Bunga Rampai Manajemen Keuangan Daerah, Yogyakarta, UPP STIM YKPN.

Indriyani, D \& Sastradipraja, U 2014, 'Pengaruh Pendapatan Asli daerah, Dana Perimbangan dan Lain-lain Pendapatan Daerah yang Sah terhadap Kinerja keuangan pemerintah Daerah (Studi pada Pemerintah Daerah Cirebon tahun Anggaran 2008-2012' Portofolio, vol. 11, no. 1, hh. 55-76.

Kuncoro, M 2004, Metode Riset Untuk Bisnis Dan Ekonomi, Yogyakarta, C.V ANDI Yogyakarta: Grafindo Persada 
Machfud, A, \& Naz'aina 2020, 'Pengaruh Pendapatan Asli daerah, Dana Perimbangan, Dana Otonomi Khusus, dan Tingkat Kemiskinan terhadap Tingkat Kemandirian Keuangan Daerah di Kabupaten/Kota Provinsi Aceh', Jurnal Manajemen Indonesia, vol. 5, no. 1, hh. 14-32.

Malau, EI, \& Parapat, EPS 2020, 'Pengaruh Pendapatan Asli Daerah (PAD) dan Belanja Modal terhadap Kemandirian Keuangan Daerah', Jurnal EK\&BI, vol. 3, no. 2, hh. 332-337.

Mamesa 1995, Sistem Akuntasi Keuangan Daerah, Jakarta, Pt. Gramedia Pustaka

Mardiasmo 2002, Otonomi dan Manajemen Keuangan Daerah, Yogyakarta, ANDI

Noholo, S, Azis, AQ \& Yusuf, N 2014, Pengaruh PAD, Dana Perimbangan, dan Belanja Modal terhadap Kinerja Pemerintah Kabupaten Bone Bolango.

Noviyanti, NA, \& Kiswanti 2016, 'Pengaruh Karakteristik Pemerintah Daerah, Temuan Audit BPK Terhadap Kinerja Keuangan Pemerintah Daerah.' Accounting Analysis Journal (Universitas Negeri Semarang), vol. 5, no. 1 .

Republik Indonesia, 2005, Peraturan Pemerintah Nomor 58 Tahun 2005 tentang Pengelolaan Keuangan Daerah, Badan Pengawas Keuangan dan Pembangunan, TGL AKSES, http://www.bpkp.go.id/uu/filedownload/4/60/906.bpkp

Republik Indonesia, 1999, Undang - undang Nomor 22 Tahun 1999 tentang Pemerintahan daerah.

Tahir, I, Mas'ud, M \& Plyriadi, A 2019, 'Faktor Faktor yang mempengaruhi Kinerja Keuangan Daerah Pada Badan Pengelolaan Keuangan dan Aset Daerah Kota Makassar (2019)', Tata Kelola, hh. 61-70

Tjahjono, A \& Oktavianti R 2016, 'Pengaruh Rasio Efektivitas Pendapatan Asli Daerah, Dana Alokasi Umum, dan Dana Alokasi Khusus terhadap Tingkat Kemandirian Keuangan Daerah di Provinsi DIY', Jurnal Kajian Bisnis, vol. 24, no. 1, hh. 25-34.

Widarjono, A 2013, Ekonometrika Pengantar dan Aplikasinya Disertai Panduan Eviews Edisi Keempat, Yogyakarta, UPP STIM YKPN. 